\title{
EFFECT OF BIOCHAR AND BIOCHAR COMBINED WITH N-FERTILISER ON SOIL ORGANIC CARBON CONTENT
}

\author{
JÁN HORÁK*, VLADIMÍR ŠIMANSKÝ
}

Slovak University of Agriculture in Nitra, Slovak Republic

HORÁK, J. - ŠIMANSKÝ, V.: Effect of biochar and biochar combined with N-fertiliser on soil organic carbon content. Agriculture (Pol'nohospodárstvo), vol. 62, 2016, no. 4, pp. 149-154.

\begin{abstract}
An experiment of different application rates of biochar and biochar combined with nitrogen fertiliser was conducted at experimental field on a Haplic Luvisol located in Nitra region of Slovakia during the growing season of spring barley (2014). The aim of this study was to evaluate the effects of biochar and biochar combined with nitrogen fertilisation on the soil organic carbon (SOC). The treatments consisted of 0,10 and $20 \mathrm{t} / \mathrm{ha}$ of biochar application (B0, B10 and B20) combined with 0,40 and $80 \mathrm{~kg} / \mathrm{ha} \mathrm{N}$ of nitrogen fertiliser applied (N0, N40 and N80). The results showed that SOC content at the beginning and end of the trial was always higher at the plots amended with biochar as compared to control plots (B0N0, B0N40 and B0N80); however, statistically significant effects were observed only at the beginning of the trial as well as at the end of trial in B20N40 treatments. Overall, the highest values of SOC contents were obtained at the beginning as well as at the end of the trial when 10 and $20 \mathrm{t} / \mathrm{ha}$ of biochar was applied together with $40 \mathrm{~kg} / \mathrm{ha} \mathrm{N}$.
\end{abstract}

Key words: biochar, biochar combined with nitrogen, fertilisation, Luvisol

One of the most important factors influencing the fertility of the soil is soil organic carbon (SOC) (Yang et al. 2012). As increasing SOC through management in agricultural systems is a slow process that is limited by the amount of biomass returned to the soil, the nutrient composition of the biomass (Kirkby et al. 2011) and the degree to which the $\mathrm{SOC}$ is exposed or protected from microbial oxidation (Hoyle et al. 2011). The content of SOC in cultivated soils, mainly in arable soils, is limited by the intensity and depth of cultivation. For this reason, the average values of SOC in arable Slovak soils ranged from $1 \%$ to $2.5 \%$ what is unsatisfactory despite a slight increase during the last period (Kobza \& Gašová 2014). The most intensively used land in Slovakia is Luvisols (Vilček \& Bedrna 2007). Šimanský et al. (2016) published ranges of SOC from $0.88 \%$ to $2.17 \%$ (to the depth $30 \mathrm{~cm}$ ) in
Luvisols of Slovakia. Intensive soil tillage practices led to a decrease in SOC; therefore, it is extremely important to pay attention to equal balance of organic compounds in the arable soils. One of such possible innovative solution may include the application of biochar, which is an important source of organic matter (Fischer \& Glaser 2012). Biochar can increase soil C storage (Koide et al. 2014) and in addition potentially influences soil health and functions and interacts with many soil properties because of the wide range of effects from biochar addition to soil (Solaiman \& Anawar 2015).

In this short communication, we verified the effects of biochar and biochar combined with nitrogen fertiliser on SOC content at the beginning and end of the trial established in a Haplic Luvisol.

The field experiment was established at the experimental site of the Slovak University of Agri-

Ing. Ján Horák, PhD. (*Corresponding author), Department of Biometeorology and Hydrology, HLEF - SUA Nitra, 94976 Nitra, Hospodárska 7, Slovak Republic. E-mail: jan.horak@uniag.sk

doc. Ing. Vladimír Šimanský, PhD., Department of Soil Science, FAFR - SUA Nitra, 94976 Nitra, Tr. A. Hlinku 2, Slovak Republic. E-mail: Vladimir.Simansky@uniag.sk 
culture (Nitra-Malanta) in Nitra region of Slovakia (latitude $48^{\circ} 19^{\prime} 00^{\prime \prime}$; longitude $18^{\circ} 09^{\prime} 00^{\prime \prime}$ ). The site is in the temperate zone, with a mean annual air temperature of $9.8^{\circ} \mathrm{C}$ and mean annual rainfall of 539 $\mathrm{mm}$. The mean air temperature and rainfall in 2014 was $10.3^{\circ} \mathrm{C}$ and $640.8 \mathrm{~mm}$, respectively. The soil type is classified as Haplic Luvisol (WRB 2006). Soil samples from soil depth of $0-10 \mathrm{~cm}$ at 10 random locations (experimental field trial) were taken before setting up the experiment. On an average, the soil contained $360.4 \mathrm{~g} / \mathrm{kg}$ of sand, $488.3 \mathrm{~g} / \mathrm{kg}$ of silt and $151.3 \mathrm{~g} / \mathrm{kg}$ of clay. SOC was $9.13 \mathrm{~g} / \mathrm{kg}$, whilst the average soil $\mathrm{pH}(\mathrm{KCl})$ was 5.71 .

In March 2014, a fully replicated $(n=3)$ factorial experiment was established, which included biochar application $(0,10$ and $20 \mathrm{t} / \mathrm{ha})$ combined with nitrogen fertiliser (Calc-Ammonium nitrate with dolomite, LAD 27) application (0, 40 and $80 \mathrm{~kg} / \mathrm{ha} \mathrm{N})$ (Table 1).

The experimental field was ploughed and all amendments were evenly applied on the soil surface and immediately incorporated into the soil combined with or without $\mathrm{N}$ fertilisation using a combinator. Then spring barley variety Malz (Hordeum vulgare L.) was sown in the experimental field (preceding crop in year 2013 was corn for silage). Biochar used for the field experiment was produced from paper fibre sludge and grain husks $(1: 1 \mathrm{w} / \mathrm{w})$ (company Sonnenerde, Austria) by pyrolysis at $550^{\circ} \mathrm{C}$ for 30 min in a Pyreg reactor (Pyreg GmbH, Dörth, Germany), and on an average, it contained $57 \mathrm{~g} / \mathrm{kg}$ of $\mathrm{Ca}$, $3.9 \mathrm{~g} / \mathrm{kg}$ of $\mathrm{Mg}, 15 \mathrm{~g} / \mathrm{kg}$ of $\mathrm{K}$ and $0.77 \mathrm{~g} / \mathrm{kg}$ of Na. Total C content was $53.1 \%$, whilst total $\mathrm{N}$ content was $1.4 \%$, the $\mathrm{C}: \mathrm{N}$ ratio was 37.9 , specific surface area (SSA) was $21.7 \mathrm{~m}^{2} / \mathrm{g}$ and content of ash was $38.3 \%$. On an average, the biochar $\mathrm{pH}\left(\mathrm{CaCl}_{2}\right)$ was
8.8. Used $\mathrm{N}$ fertiliser was calcium ammonium nitrate.

Three randomly distributed soil cores $(0-0.1 \mathrm{~m})$ per plot were taken at each soil sampling and pooled to produce an average representative sample for the determination of SOC at the beginning (after incorporation of biochar and nitrogen fertiliser to the soil in March) and at the end of the trial (October) in 2014. The SOC content by the wet combustion method (oxidation of organic matter by a mixture of $\mathrm{H}_{2} \mathrm{SO}_{4}$ and $\mathrm{K}_{2} \mathrm{Cr}_{2} \mathrm{O}_{7}$ with titration using Mohr's salt) was determined according to Tyurin (Dziadowiec \& Gonet 1999). One-way analysis of variance and the least significant difference method was used to compare the treatment means for the two levels of biochar and three levels of nitrogen application at $p<0.05$.

The SOC contents at the beginning and the end of the trial are presented in Figure 1. The soil analysis showed that SOC content at the beginning and end of the trial was always higher at the plots amended with biochar as compared to control plots. The soils that included biochar (10 and $20 \mathrm{t} / \mathrm{ha}$ ) combined with 0,40 and $80 \mathrm{~kg} / \mathrm{ha} \mathrm{N}$ significantly increased the $\mathrm{SOC}$ at the beginning of the field trial. However, SOC content was significantly higher at the end of the field trial only in the B20N40 treatment as compared to B0N40. The SOC content generally decreased in the order $\mathrm{B} 20 \mathrm{~N} 0>\mathrm{B} 10 \mathrm{~N} 0>\mathrm{B} 0 \mathrm{~N} 0$ when no nitrogen was applied and the same trend was found in the treatments fertilised with $40 \mathrm{~kg} / \mathrm{ha} \mathrm{N}$ following the order B20N40 $>\mathrm{B} 10 \mathrm{~N} 40>\mathrm{B} 0 \mathrm{~N} 40$ and $\mathrm{B} 20 \mathrm{~N} 80>\mathrm{B} 10 \mathrm{~N} 80>\mathrm{B} 0 \mathrm{~N} 80$. By the end of the experiment, SOC contents of soils amended with 10 and $20 \mathrm{t} / \mathrm{ha}$ of biochar (B10N0 and B20N0) were increased by $20 \%$ and $79 \%$, respectively, relative to

T a b 1 e 1

Treatments including individual amounts of applied $\mathrm{N}$ fertilisers (first column) and biochar (second, third and fourth columns)

\begin{tabular}{|c|c|c|c|}
\hline \multirow{2}{*}{$\begin{array}{c}\text { Amount of N fertiliser } \\
\text { application level (N) } \\
{[\mathrm{kg} / \mathrm{ha}]}\end{array}$} & 0 & 10 & 20 \\
\cline { 2 - 4 } & B0N0 & B10N0 & B20N0 \\
40 & B0N40 & B10N40 & B20N40 \\
80 & B0N80 & B10N80 & B20N80 \\
\hline
\end{tabular}


the control (B0N0). The SOC contents of soils fertilised with 40 and $80 \mathrm{~kg} / \mathrm{ha} \mathrm{N}$ combined with 10 and $20 \mathrm{t} / \mathrm{ha}$ of biochar were also higher by $37 \%, 77 \%$ and $8 \%, 37 \%$, respectively, for B10N40, B20N40 and $\mathrm{B} 10 \mathrm{~N} 80 \mathrm{~B} 20 \mathrm{~N} 80$ as compared to the controls $\mathrm{B} 0 \mathrm{~N} 40$ and B0N80. The highest values of SOC contents were obtained at the beginning as well as the end of the trial when 10 and $20 \mathrm{t} / \mathrm{ha}$ of biochar was applied together with $40 \mathrm{~kg} / \mathrm{ha} \mathrm{N}$. This effect appears to be caused by the increase of soil organic matter (SOM) resistance to microbial degradation. This can be linked to the priming effect as reported by Fisher and Glaser (2012). Biochar could cause a positive priming effect because of its high surface area providing habitat for microorganisms and because of the input of partly labile $\mathrm{C}$ substrate (condensates). The SOC is an indicator of SOM, which aerates the soil and helps to retain water and nutrients. Some studies also reported that SOC was increased after the application of different biochar types (Kimetu \& Lehmann 2010; Agegnehu et al. 2016).

Although the SOC in our field trial increased after biochar application, the levels are still considered low/middle, which suggests that further biochar application would be beneficial to our soils and which could also positively change nutrient status and water retention capacity of soil and availability for plants. However, before the final recommendations and application of biochar and biochar combined with $\mathrm{N}$ fertiliser in different doses to the other soils in Slovakia, it is necessary to look closer on the other (positive or negative) effects on soil characteristics, transfer elements into cultivated plants and yield parameters.

Acknowledgements. This study was supported by Slovak Grant Agency VEGA, No. 1/0604/16, and Slovak Research and Development Agency under the contract No. APVV-0512-12.

\section{REFERENCES}

AGEGNEHU, G. - BASS, A.M. - NELSON, P.N. - BIRD, M.I. 2016. Benefits of biochar, compost and biocharcompost for soil quality, maize yield and greenhouse gas emissions in a tropical agricultural soil. In $\mathrm{Sci}$ ence of The Total Environment, vol. 543, pp. 295306. DOI: 10.1016/j.scitotenv.2015.11.054

DZIADOWIEC, H. - GONET, S.S. 1999. Przewodnik metodyczny do badań materii organicznej gleb [Methodical guide-book for soil organic matter studies]. Prace Komisji Naukowych Polskiego Towarzystwa Gleboznawczego, N. 120, Komisja chemii gleb, Zespół Materii Organicznej Gleb, N II/16, 65 p.

FISCHER, D. - GLASER, B. 2012. Synergisms between compost and biochar for sustainable soil ameliora-

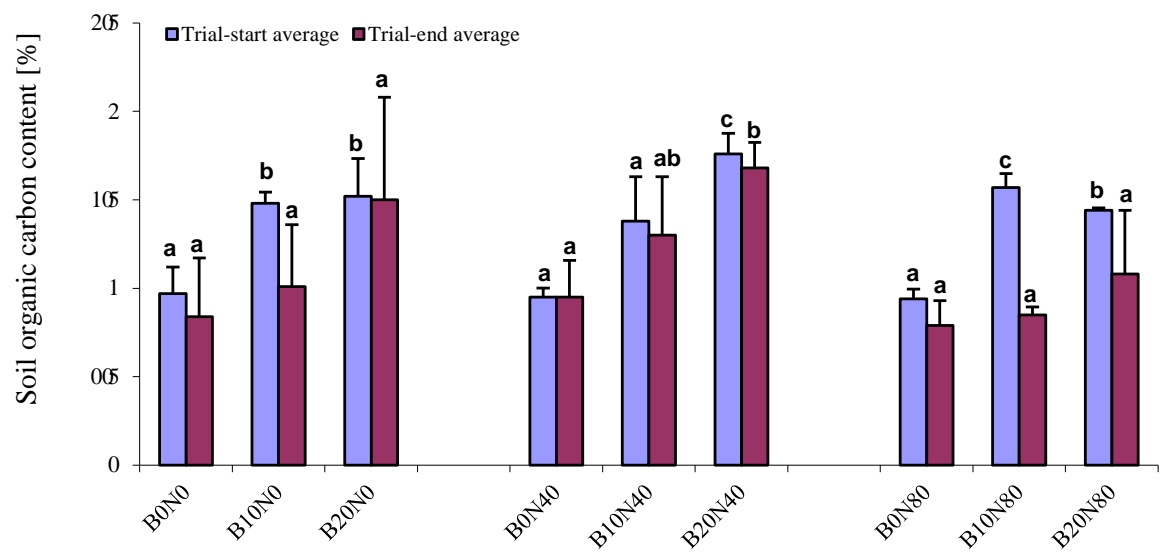

Treatments

Figure 1. Effect of biochar treatments on soil organic carbon content

Different letters between columns indicate that treatment means over the sampling dates are significantly different at $p<0.05$ according to the least significant difference multiple-range test 
tion. In KUMAR, S. (Ed.). Management of Organic Waste. In Tech Europe, Rijeka. pp. 167-198.

HOYLE, F.C. - BALDOCK, J.A. - MURPHY, D.V. 2011. Soil organic carbon Role in rainfed farming systems. In TOW, P. - COOPER, I. - PARTRIDGE, I. - BIRCH, C. (Eds.). Rainfed Farming Systems. Dordrecht : Springer, pp. 339-361.

KIMETU, J. - LEHMANN, J. 2010. Stability and stabilisation of biochar and green manure in soil with different organic carbon contents. In Australian Journal of Soil Research, vol. 48, pp. 577-585. DOI: 10.1071/ SR 10036

KIRKBY, C.A. - KIRKEGAARD, J.A. - RICHARDSON, A.E. - WADE, L.J. - BLANCHARD, C. - BATTEN, G. 2011. Stable soil organic matter: A comparison of $\mathrm{C}: \mathrm{N}: \mathrm{P}: \mathrm{S}$ ratios in Australian and other world soils. In Geoderma, vol. 136, pp. 197-208. DOI: 10.1016/j. geoderma.2011.04.010

KOBZA, J. - GAŠOVÁ, K. 2014. Soil monitoring system as a basic tool for protection of soils and sustainable land use in Slovakia. In Journal of Agricultural Science and Technology, vol. 4, pp. 504-513.

KOIDE, R.T. - NGUYEN, B.T. - SKINNER, R.H. DELL, C.J. - PEOPLES, M.S. - ADLER, P.R. - DROHAN, P.J. 2014. Biochar amendment of soil improves resilience to climate change. In GCB Bioenergy, vol. 7, no. 5, pp. 1084-1091. DOI: 10.1111/gcbb.12191

ŠIMANSKÝ, V. - BALASHOV, E. - HORÁK, J. 2016. Water stability of soil aggregates and their ability to sequester carbon in soils of vineyards in Slovakia. In Archives of Agronomy and Soil Science, vol. 62, no. 2, pp. 177-197. DOI: 10.1080/03650340.2015.1048683

ŠIMANSKÝ, V. - HORÁK, J. - IGAZ, D. - JONCZAK, J. - MARKIEWICZ, M. - FELBER, R. - RIZHIYA, E.Y. - LUKAC, M. 2016. How dose of biochar and biochar with nitrogen can improve the parameters of soil organic matter and soil structure? In Biologia, vol. 71, no. 9, pp. 989-995. DOI: 10.1515/biolog-2016-0122

SOLAIMAN, Z.M. - ANAWAR, H.M. 2015. Application of Biochars for Soil Constraints: Challenges and Solutions. In Pedosphere, vol. 25, no. 5, pp. 631-638. DOI: $10.1016 / \mathrm{S} 1002-0160(15) 30044-8$

VILČEK, J. - BEDRNA, Z. 2007. Vhodnost' polnohospodárskych pôd a krajiny Slovenska na pestovanie rastlin [The eligibility of agricultural soils and landscapes of Slovakia for the cultivation of plants]. Bratislava : Výskumný ústav pôdoznalectva a ochrany prírody, pp. 248

YANG, X. - REN, W. - SUN, B. - ZHANG, S. 2012. Effects of contrasting soil management regimes on total and labile soil organic carbon fractions in a loess soil in China. In Geoderma, vol. 177-178, pp. 49-56. DOI: $10.1016 /$ j.geoderma.2012.01.033

Received: December 14, 2016 